\title{
地形性降雨の非地形性降雨に対する 非線形効果を考慮した短時間降雨予測手法 A SHORT-TERM RAINFALL PREDICTION TAKING INTO CONCIDERATION NONLINEAR EFFECT OF NON-OROGRAPHIC RAINFALL ON ORGRAPHIC RAINFALL
}

\author{
中北英一 1 ・寺園正彦 2 \\ Eiichi NAKAKITA and Masahiko TERAZONO \\ 1正会員 工博 京都大学教授 防災研究所（干611-0011 宇治市五ヶ庄） \\ 2学生会員 工学士 京都大学修士課程 工学研究科（干615-8503 京都市西京区京都大学桂)
}

\begin{abstract}
A nonlinear effect of non-orographic rainfall on orographic rainfall is introduced into a short-term rainfall prediction method which uses Tatehira's orographic rainfall model. In the previous paper, orographic rainfall is assumed to be simply proportional to non-orographic rainfall. In the seeder-feeder mechanism, which is the most important part in the generation of orographic rainfall, ratio of capturing cloud drops by raindrops (by non-orographic rainfall) $c$ is taking a vital role. However, $c$ is not proportional to the non-or0graphic rainfall intensity. In this paper, therefore, c is assumed to be a nonlinear function in terms of the non-orographic rainfall and a method of solving simultaneous equations composed of the nonlinear function and the conservation equation of cloud drop is proposed. As a result, it is found that, when the nonlinear effect is taken into account, computed orographic rainfall becomes much smaller and that assumed depth of atmospheric layer of hundred meters is not enough. Therefore, the computation method is further modified so that orographic rainfall can be generated from multi layers.
\end{abstract}

Key Words : rainfall prediction, orographir rainfall, radar, GPV, translation model,

\section{1. 序論}

短時間降雨予測の汎用手法として，雨域の平行移動や 回転といった動きを表現できる椎葉ら战による移流モデ ルが広く用いられている。しかし，全国合成レーダー情 報を予測の対象とする場合，西日本には台風に伴う降雨 帯全体があり，東北〜北海道には前線による降雨帯があ る場合が多々あり，両者の動きはまったく異なる，その 場合, 現在の移流モデルではこの両者の雨域の移動を同 時に表現することはできない，一方，台風時には風速が 強く, 地形性降雨が卓越する場合も多い.

こういった問題意識から，中北ら ${ }^{2)}$ は，移流モデルを 改良し, 台風時に, 台風の位置情報と速度情報を加味し たモデルでベクトルを表現し，台風性降雨の雨域に対し ては台風の移動と回転といった挙動たけでなく, 台風の 影響の及ばない遠方でのベクトルも正確にとらえられる 新しい移流モデルを提案し.さらにこのモデルに対して, GPV 情報を用い，地形が降雨分布に及ぼす影響，すな
わち，立平モデルによる地形性降雨の概念を導入する手 法を提案した。

本研究では, 中北ら ${ }^{2)}$ の研究をさらに進め, 地形性降 雨を算定寸る際に水蒸気の収支について考慮し，地形性 降雨の非地形性降雨に対寸る線形性を仮定していた問題 についても解決を図った。 また，中北ら²は地上から高 度が約1000mにおける風速などの值を代表值として，層 厚100 mで地形性降雨を算定していたが，今回，大気中 の複数の層を想定して地形性降雨の算定を行った. 予測 の対象としては 2004年台風6号を用いて，降雨予測計算 を行い，予測精度向上を目指した。

\section{2. 水蒸気収支を考慮した立平モデルと従来の地 形性降雨の算定手法}

\section{（1）水蒸気収支を考慮した立平モデル}

立平モデル3゙とは，地形性降雨を算定するためのモデ 
ルであり，地形の影響による降雨の停滞を良く捉え，図 -1に示すように以下のような特徵がある.

（ア）地形性上昇風によって山を越えるときに，凝結し た雲水から降水に転換する.

(イ)雲粒から雨滴への成長過程も考慮している.

(ウ)非地形性降雨による降水雲粒補足 (Seeder Feeder 機構)を考慮している.

（エ）過去（風上）に地形性降雨として落下した雲水を 気塊から逐次取り除く.

具体的には，流れに沿った雲水量の時間変化を，

$$
\frac{d L}{d t}=-c L-a\left(L-L_{\mathrm{C}}\right)+W G-W L \frac{\partial \ln P}{\partial z}
$$

によってモデル化し, 右辺最終項を無視して解析的に積 分する手法である. 右辺第 1,2 項が図-1における地形性 降雨となる.

また，本研究では，中北ら2てでは十分には考慮されて いなかった気塊の流れに沿った水蒸気の収支も考慮して いる，すなわち，流れに沿った雲水量および水蒸気量の 時間変化を,

$$
\begin{aligned}
& \left\{\begin{array}{l}
\frac{d L}{d t}=-c L-a\left(L-L_{\mathrm{c}}\right)+W G \quad \quad\left(\rho_{\mathrm{v}} \geq \rho_{\mathrm{s}}\right) \\
\frac{d \rho_{\mathrm{v}}}{d t}=-W G
\end{array}\right. \\
& \begin{cases}\frac{d L}{d t}=-c L-a\left(L-L_{\mathrm{c}}\right) & \left(\rho_{\mathrm{v}}<\rho_{\mathrm{s}}\right) \\
\frac{d \rho_{\mathrm{v}}}{d t} & =0\end{cases}
\end{aligned}
$$

とし，モデル化を行った。ここで，Lは単位体積あたり の雲水の質量 (雲水量 $;\left[\mathrm{g} / \mathrm{m}^{3}\right]$ ), 図中の $L_{0}$ は初期の雲 水量で0とした. cはSeeder Feeder機構による非地形性降 水雲粒補足率で，雨滴が落下しながら雲を単位時間当た り掃く体積と掃く効率の積で表され，雨滴の粒形分布を 通し非地形性降雨強度 $R_{\mathrm{N}}$ の関数である。また、 $a$ は雲粒 自身による降水一の成長 (Auto Conversion) の割合で10 ${ }^{4}[/ \mathrm{s}], L \mathrm{c}$ は降水一と転換する限界の雲水量で $1\left[\mathrm{~g} / \mathrm{m}^{3}\right]$ と し，W は斜面に沿った気塊の上昇速度 $[\mathrm{m} / \mathrm{s}], G$ 飽和気 塊の単位距離上昇によるLの増加量 $\left[\mathrm{g} / \mathrm{m}^{3} \cdot \mathrm{m}\right]$ である. $\rho$ は水蒸気量 $\left[\mathrm{g} / \mathrm{m}^{3}\right], \rho_{\mathrm{s}}$ は飽和水蒸気量 $\left[\mathrm{g} / \mathrm{m}^{3}\right]$ である.た だし，Gは対象高度の気温をべースに解析的に $d \rho_{s} / d z$ の值 を与える.

流入する雲水量を $L_{0}$ とし，図-1に示すように 1 メッ シュにわたって(2)式を積分すると流出する雲水量 $L$ は,

$$
L=\left(L_{0}-\frac{a L_{\mathrm{C}}+W G}{c+a}\right) \exp (-(c+a) \Delta t)+\frac{a L_{\mathrm{C}}+W G}{c+a}
$$

となる．ここで， $\Delta t$ は気塊が1メッシュを通過する時間 $[\mathrm{s}]$ である。 また，地形性降雨強度 $R_{0}[\mathrm{~mm} / \mathrm{h}]$ は，流出寸 る雲水量 $L$, 凝結し増加した雲水量 $W G \Delta t$, そして流入 する雲水量 $L_{0}$ の収支を考えると，

$$
R_{\mathrm{O}}=\frac{L_{0}+W G \Delta t-L}{\Delta t} \times 3.6 \times H
$$

となる.ここでHは地形性降雨算定の対象と寸る気塊の 厚さ，すなわち層厚 $[\mathrm{m}]$ である. また，流出した雲水量 Lは，次のメッシュに流入する雲水量 $L_{0}$ となる.

\section{（2）従来の手法}

まず中北 $ら^{2)}$ は，Kataoka et al. ${ }^{4)}$ の方法に従って，全計 算領域において, 風速 $10[\mathrm{~m} / \mathrm{s}]$, 非地形性降雨強度 4 $[\mathrm{mm} / \mathrm{h}]$ として，気塊が山を迂回せずに上昇すると仮定 し，16方位の風向ごとに地形性降雨強度分布を計算する ことにより，16の基準地形性降雨分布 $R_{\mathrm{g}, \mathrm{dir}}(x, y)$ を作成し た. 地形性降雨の風速と非地形性降雨強度に対寸る線形 性と, レーダー観測降雨が地形性降雨と非地形性降雨の 合成であるとの仮定から，

$$
\left\{\begin{array}{l}
R_{\text {rader }}=R_{\mathrm{O}}+R_{\mathrm{N}} \\
R_{\mathrm{O}}=R_{\mathrm{g}, \mathrm{dir}} \times \frac{R_{\mathrm{N}}}{4[\mathrm{~mm} / \mathrm{h}]} \times \frac{V}{10[\mathrm{~m} / \mathrm{s}]}
\end{array}\right.
$$

の 2 式を連立することにより, 地形性降雨の算定を行っ た. ここで， $R_{\text {radar }}$ は，レーダー観測降雨強度 $[\mathrm{mm} / \mathrm{h}]$ で あり， $R_{0}$ は地形性降雨強度 $[\mathrm{mm} / \mathrm{h}], R_{\mathrm{N}}$ は非地形性降雨 強度 $[\mathrm{mm} / \mathrm{h}], V /$ は風速 $[\mathrm{m} / \mathrm{h}], R_{\mathrm{g}, \mathrm{dir}}$ は対応するメッシュ の風向から抽出した基準地形性降雨分布における地形性 降雨強度 $[\mathrm{mm} / \mathrm{h}]$ である. 当初, 中北 $5^{2)}$ は風速および風 向を雨域の移流ベクトルで代用していたが，その後，下 層の風の境界条件や山岳に沿って, 等高度面になおすこ とのできるの座標系を用いて, 地上から高度が約 $1000 \mathrm{~m} の$ $\mathrm{GPV} \cdot \mathrm{AMeDAS}$ 合成風の風速，風向を用いて地形性降 雨を算定した。 $\sigma$ 座標系は, $\sigma=(\mathrm{z}-h(x, y)) /(H-h(x, y))$ で表さ れる. ここで, $h(x, y)$ は地点 $(x, y)$ での地表の標高, Hは解 析対象上端の高度で，Hを $11 \mathrm{Km}$ として時間的不変とす る. すなわち標高 $h(x, y)$ が0mの海上において高度 $1000 \mathrm{~m}$ は $\sigma=1 / 11$ となる. しかしながら，この手法では，16の基 準地形性降雨分布作成の際に, 風向・風速が一様として いるために実際の風向に沿った雲水量の流出入に伴う地 形性降雨強度が算定できていない，また，地形性降雨強 度は，風速に関して線形ではない。

これらの問題を解決するために，中北ら ${ }^{2)}$ は, 雲水量を $\mathrm{GPV}$ ・ AMeDAS 合成風の風向に沿って流出入させるこ とにより，4[mm/h]の非地形性降雨のみを基準として導 入した，基準地形性降雨分布を一つだけ作成する手法 を提案した. すなわち,

$\left\{\begin{array}{l}R_{\text {rader }}=R_{\mathrm{O}}+R_{\mathrm{N}} \\ R_{\mathrm{O}}=R_{\mathrm{g}, \mathrm{gpv}} \times \frac{R_{\mathrm{N}}}{4[\mathrm{~mm} / \mathrm{h}]}\end{array}\right.$

の2式を連立し，地形性降雨を算定する． $R_{\mathrm{g}, \mathrm{gpv}}$ は作成し た一つの基準地形性降雨分布における地形性降雨強度 $[\mathrm{mm} / \mathrm{h}]$ である. この手法 $\left(\right.$ 中北ら $\left.{ }^{2}\right)$ により, 地形性降雨 の風速に対する線形性の仮定を排除した.

しかしながら，非地形性降雨強度4 [mm/h] と仮定した 基淮地形性降雨 $R_{\mathrm{g}}$ を用いて，地形性降雨を算定している 
ため, 地形性降雨の非地形性降雨に対する線形性の仮定 を解決するに到っていない. 本研究では，この問題につ いて解決を図っていく.

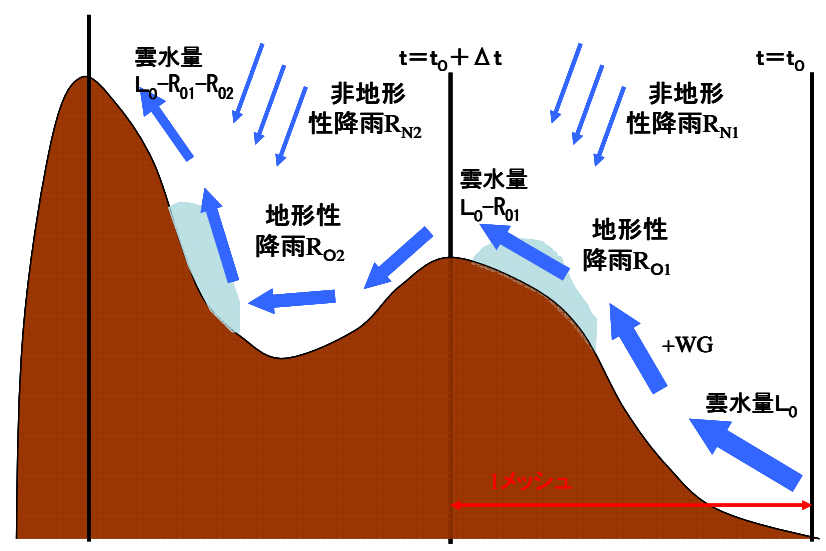

図-1 地形性降雨算定方式 $\left(R_{01}, R_{02}\right.$ は水色部分は地形成降雨)

\section{3. 地形性降雨の非地形性降雨に}

\section{対する非線形効果}

\section{（1）地形性降雨の非地形降雨に対する非線形効果}

(1)式によると，地形性降雨が非地形性降雨によって強 度が増すのは、上空からの降水雲粒捕捉(Seeder Feeder 機構)によるものである. 2. (2)に示すように，中北ら²) は， Kataoka et al. ${ }^{4)}$ の方法に従い，その捕捉率cとして4 [mm/h] の非地形降雨の時の值を用い， $R_{\mathrm{g}, \mathrm{gpv}}$ を算定し，その上で 地形性降雨の強度 $R_{\mathrm{O}}$ が非地形性降雨の強度 $R_{\mathrm{N}}$ に線形に 比例すると仮定し，地形性降雨の算定を行ってきた。し かし立平ら ${ }^{3)}$ によると, 捕捉率 $C$ は非地形性降雨強度 $R_{\mathrm{N}}$ に 対して線形ではなく，加えて式(4)と式(5)から，その捕 捉率 $c$ に対しても地形性降雨強度 $R_{0}$ は線形ではない.す なわち, 地形性降雨強度 $R_{\mathrm{O}}$ と非地形性降雨強度 $R_{\mathrm{N}}$ に線 形関係はない。これを以下，地形性降雨の非地形性降雨 に対する非線形効果と呼ぶことにする.

本研究では，地形性降雨の非地形性降雨に対する非線 形効果を考慮し，レーダー観測降雨を地形性降雨と非地 形性降雨に分離して，予測計算を行う方法を提案する. まず，レーダー観測降雨から分離を考える際のみ，雲粒 自身による降水への成長 (Auto Conversion)の影響は小さ いと仮定し，これを省略する.この仮定により，

$$
\left\{\begin{array}{l}
c=0.6778 R_{\mathrm{N}}^{0.731} \\
\frac{d L}{d t}=-c L+W G \\
R_{\text {rader }}=R_{\mathrm{O}}+R_{\mathrm{N}}
\end{array}\right.
$$

の3式を連立することで地形性降雨を算定する。(10)式は 立平ら ${ }^{3)}$ 論文の中で示されている捕捉率 $c$ と非地形性降 雨強度 $R_{\mathrm{N}}$ の值をフィッティングすることにより得られた.
(11)式は雲水量の連続式であり，(12)式はレーダー情報 が地形性降雨と非地形性降雨の合成であると仮定した式 である. 具体的な解法を以下に示す。

流入する雲水量を $L_{0}$ とし，1メッシュにわたつて(11)式 を積分すると, 流出する雲水量 $L$ は,

$$
L=\left(L_{0}-\frac{W G}{c}\right) \exp (-c \Delta t)+\frac{W G}{c}
$$

となる.ここで，前述したように $\Delta t$ は気塊が1メッシュ を通過する時間 $[\mathrm{s}]$ である. 地形性降雨強度 $R_{\mathrm{O}}[\mathrm{mm} / \mathrm{h}]$ は， 次のメッシュに流出する雲水量 $L$, メッシュ内で凝結し 増加した雲水量 $W G \Delta t[\mathrm{~g}]$, そして流入する雲水量 $L_{0}$ の収 支を考えると，

$$
R_{\mathrm{O}}=\frac{L_{0}+W G \Delta t-L}{\Delta t} \times 3.6 \times H
$$

である.ここでHは地形性降雨算定の対象とする気塊の 厚さ，すなわち層厚 $[\mathrm{m}]$ である. (13)式を(14)式に代入す ると,

$R_{\mathrm{O}}=\frac{L_{\mathrm{O}}(1-\exp (-c \Delta t))-\frac{W G}{c}(1-\exp (-c \Delta t))+W G \Delta t}{\Delta t \quad \times 3.6 \times H}$

となる. $\exp (-c \Delta t)$ の項に対し, テーラー展開を行うと,

$$
\begin{gathered}
\exp (-c \Delta t)=1-c \Delta t+\frac{c^{2}}{2 !} \Delta t^{2}-\frac{c^{3}}{3 !} \Delta t^{3}+ \\
\cdots-\frac{c^{n+1}}{(n+1) !} \Delta t^{n+1}
\end{gathered}
$$

となり，この式を(15)式に代入し整理すると，

$$
\begin{aligned}
& R_{\mathrm{O}} /(3.6 \times H)=\left(L_{0}+\frac{W G \Delta t}{2 !}\right) c \\
&-\left(\frac{L_{0} \Delta t}{2 !}+\frac{W G \Delta t^{2}}{3 !}\right) c^{2}+ \\
& \cdots \cdots+(-1)^{n-1} \times\left(\frac{L_{0} \Delta t^{n-1}}{n !}+\frac{W G \Delta t^{n}}{(n+1) !}\right) c^{n} \\
&+(-1)^{n} \times\left(\frac{L_{0} \Delta t^{n}}{(n+1) !}\right) c^{n+1}
\end{aligned}
$$

となる. 本研究では, $n=30$ として, テーラー展開を行っ た. (10)式を(17)式に代入すると， $R_{\mathrm{O}}$ は $R_{\mathrm{N}}$ の関数となり， これを(12)式と連立することで地形性降雨を算定するこ とができる。

\section{(2) 試験的に行った分離の結果}

3. (1)で示した方法により，実際に考えられる值として， 流入する雲水量 $L_{0}$ を $0.2\left[\mathrm{~g} / \mathrm{m}^{3}\right], 1$ メッシュの通過時間 $\Delta t$ を600.0[s], 層厚 $H$ を $100[\mathrm{~m}]$ とおいて上昇速度 $W$ を $0.5[\mathrm{~m} / \mathrm{s}], 1.0[\mathrm{~m} / \mathrm{s}], 1.5[\mathrm{~m} / \mathrm{s}]$ と変えて試験的に地形性降 雨と非地形性降雨の分離を行った。算定された地形性降 雨強度を図-2に示す. 非地形性降雨が4[mm/h] の時の捕 捉率 $c$ の值を用いて求めた基準地形性降雨強度 $R_{\mathrm{g}, \mathrm{gpv}}$ に地 形性降雨強度が線形であると仮定していた手法(中北ら 2) では，地形性降雨強度をかなり過大に算定していたこ とが，図-2より判明した。 


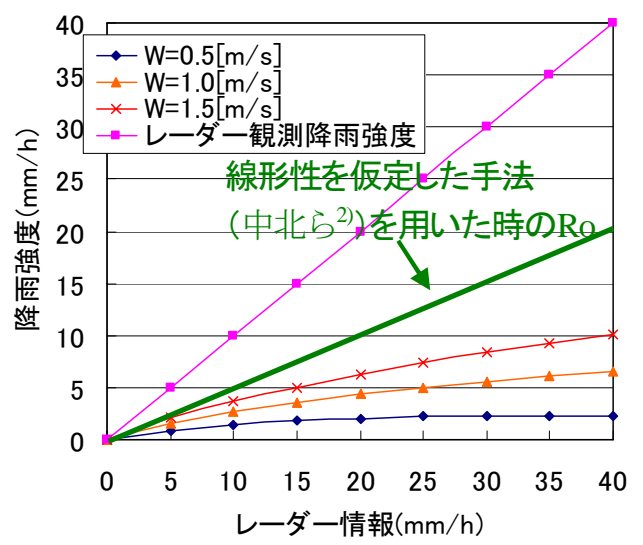

図-2＼cjkstart非線形性を考慮して算定された地形性降雨強度

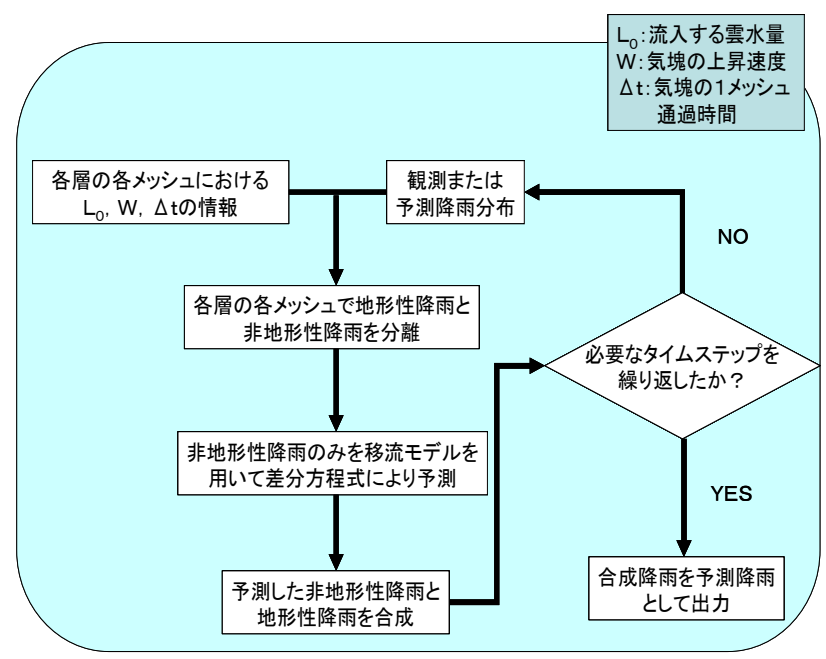

図-3 複数の層を考慮した地形性降雨の算定
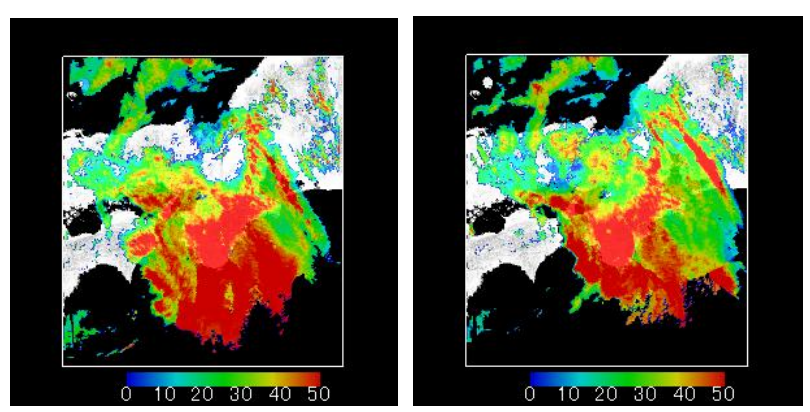

初期時刻 (午前10時) 実況降雨

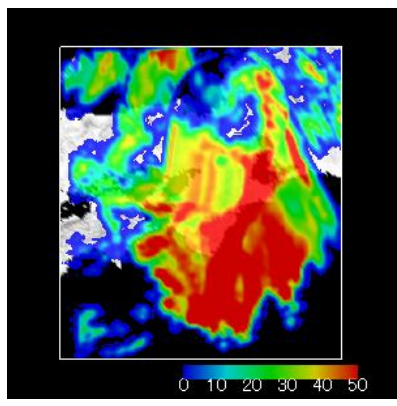

1時間後予測降雨
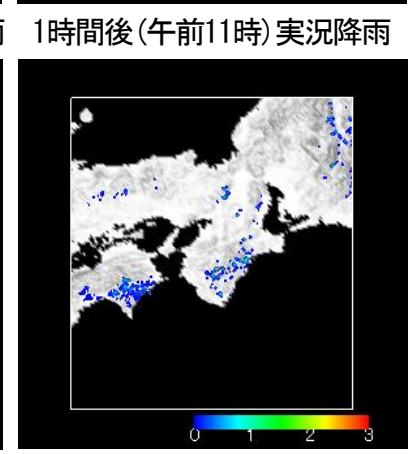

1時間後予測地形性降雨

図-4 降雨予測結果

\section{（3）降雨予測とその結果についての検証}

2004年に日本に上陸した台風6号を対象として，図-3 に示寸予測手順に従って予測を行う。各タイムステップ, 各メッシュでの地形性降雨, 非地形性降雨の分離手法に 本研究で提案した手法を用いた以外, 日本全域の合成 レーダー情報を対象とした移流ベクトルの同定方法，非 地形性降雨の移流計算手法等は中北 $\check{(2)}^{2)}$ と同じである. また各層の各メッシュに流入する雲水量を求める際は, Auto Conversionを考慮している. 用いたデータは, 日本 全国に配置された26基のレーダー雨量計が観測する5分 ごとのレーダ雨量を，10分ないしは60分ごとに得られる 地上雨量計を用いてオンラインで補正を行い，5分間隔 で全国の雨量分布を表す3次メッシュ(第3次地域区画緯 度間隔30秒 経度間隔 45 秒で, 約 $1 \mathrm{~km} \times 1 \mathrm{~km})$ ごとの連続 的な合成レーダ雨量を国土交通省が作成したものである. 範囲は, 経度23度20分 (2800メッシュ) ×緯度23度 $(1840$ メッシュ)である. 本研究ではこの緯度, 経度のメッ シュデータを，レーダーデータの中心 (東経136度30分・ 北緯35度40分)を投影中心としてガウス・クリューゲル 図法にて投影を行い，1kmメッシュの縦2653km×横 $2350 \mathrm{~km}$ のデータとした. 地上から高度が約 $1000 \mathrm{~m} の$ 風 速, 水蒸気量, 飽和水蒸気量を代表值として層厚を 100mとし，地形性降雨を算定した。初期時刻は2004年6 月21日午前10時としており, 初期時刻の実況降雨, 1 時 間後の実況降雨と予測降雨および予測地形性降雨の結果 を図-4に示す．結果からわかるように，地形性降雨の非 地形性降雨に対寸る非線形効果を考慮した際, 地形性降 雨強度, 分布ともに, 図には示さないが線形性を仮定し た従来の手法 $\left(\right.$ 中北ら $\left.ら^{2}\right)$ に比べて, 大変小さく算定され ている.これは, 従来の方法で用いられていた層厚 100mが現実的には大変薄いということを意味している. このことを踏まえ, 次章で示すように本研究では複数の 層とその層厚を考えることにより，問題の解決を図った.

\section{4. 複数の層を想定した地形性降雨の算定手法}

複数層を考慮する場合は， $\sigma$ 座標をもって地上から高 度が約 $200 \mathrm{~m}, 400 \mathrm{~m}, 1000 \mathrm{~m}, 2000 \mathrm{~m}, 3000 \mathrm{~m}, 4000 \mathrm{~m}$, $5000 \mathrm{~m}$ における風速, 水蒸気量, 飽和水蒸気量を代表值 として，それぞれの層厚を200m, 200m, 1000m, $1000 \mathrm{~m}, 1000 \mathrm{~m}, 1000 \mathrm{~m}, 1000 \mathrm{~m}$ と地形性降雨の算定 を行った. また，最下層(高度が約 $200 \mathrm{~m}$ )における地形性 降雨と非地形性降雨の合成をレーダー観測降雨と仮定し た手法と地上からの高度が約2000mにおける地形性降雨 と非地形性降雨の合成をレーダー観測降雨と仮定した手 法で予測を行った。これらの手法により, 地形性降雨の プロセスを通した上での，上下層の降雨強度の違いを考 慮できる. 
（1）最下層における地形性降雨と非地形性降雨の合成を レーダー観測降雨と仮定した手法

この手法では，レーダーで観測された降雨が最下層す なわち本研究における地上からの高度が約 $200 \mathrm{~m} の$ 降雨 であると仮定して予測を行っている. 具体的にはまず, 最下層である地上からの高度が約200mで3. (1)で示した 方法により, 地形性降雨と非地形性降雨に分離を行い, ここで算定された非地形性降雨を直上の層での地形性降 雨と非地形性降雨の合成であるとし，地形性降雨と非地 形性降雨とに分離を行う。この操作を上層にむけて，地 上からの高度が約5000mまでの7層で繰り返すことによ り, 各々の層での地形性降雨を積算することで地形性降 雨を算定する. またこの手法では，図-5に示すように, 立平モデルにおいて地形の影響をうけて発生した雲水量 が少ない上層まで地形性降雨と非地形性降雨の算定が行 われるため, 求められた非地形性降雨は地形の影響をう けていない純粋な非地形性降雨となる。

\section{（2）地上から高度が約2000mにおける地形性降雨と非地 形性降雨の合成をレーダ一観測降雨と仮定した手法}

この手法では，レーダーで観測された降雨が本研究に おける地上からの高度が約2000mの降雨であると仮定し て予測を行う。具体的には，上層に向けては，地上から の高度が約2000mから約5000mまでの4層で，4. (1)で示し た操作を繰り返す．また下層に向けては，地上からの高 度が約 $2000 \mathrm{~m}$ の直下の層における地形性降雨を，地上か らの高度が約2000mの地形性降雨と非地形性降雨の合成 であるレーダー観測降雨を非地形降雨として，(17)式に より算定寸る. 求められた地形性降雨を上空からの非地 形性降雨と合成し，さらに直下の層に対寸る非地形性降 雨と寸ることで, 地形性降雨を算定することができる. この操作を, 地上からの高度が約200mまでの3層で繰り 返す。こうして求められた, 上層, 下層の各々の層での 地形性降雨を積算することにより，地形性降雨を算定す ることができる.

\section{（3）算定手法にあたつての条件}

各層における風速場および水蒸気場の推定方法として, 短時間の大気変化を見るために, Nakakita et al. ${ }^{5)}$ の短時 間降雨予測手法中の大気場の推定方法を用いて, GPV 情報を1時間ごと, 水平方向 $3 \mathrm{~km}$ 四方, 垂直方向15層 (SFC, 975, 950, 925, 900, 850, 800, 700, 500, 400, 300，250，200，150，100hPa の等圧面)のデー夕に内挿 し，このGPV情報とAMeDAS観測值を併用して，大気 場 (風向·風速·水蒸気量·飽和水蒸気量)を推定した. ま た, 飽和気塊の単位距離上昇したときのLの増加 $G$ $\left[\mathrm{g} / \mathrm{m}^{3} \cdot \mathrm{m}\right]$ の值は, 中北 $5^{2)}$ の仮定のもと, 国際標準大 気に基づき，高度 $200 \mathrm{~m}, 400 \mathrm{~m}, 1000 \mathrm{~m}, 2000 \mathrm{~m}, 3000 \mathrm{~m}$, 4000m，5000mの層でそれぞれ，一定値7.4× $10^{-4}\left[\mathrm{~g} / \mathrm{m}^{3} \cdot \mathrm{m}\right]$,
$6.9 \times 10^{-4}\left[\mathrm{~g} / \mathrm{m}^{3} \cdot \mathrm{m}\right], \quad 5.4 \times 10^{-4}\left[\mathrm{~g} / \mathrm{m}^{3} \cdot \mathrm{m}\right], \quad 3.6 \times 10^{-4}\left[\mathrm{~g} / \mathrm{m}^{3} \cdot \mathrm{m}\right]$, $2.5 \times 10^{-4}\left[\mathrm{~g} / \mathrm{m}^{3} \cdot \mathrm{m}\right], \quad 1.7 \times 10^{-4}\left[\mathrm{~g} / \mathrm{m}^{3} \cdot \mathrm{m}\right], \quad 1.0 \times 10^{-4}\left[\mathrm{~g} / \mathrm{m}^{3} \cdot \mathrm{m}\right]$ とした. さらに，図-6に示すように，ある層に対する非 地形性降雨は, 直上の層の非地形性降雨と地形性降雨の 合成であるとし地形性降雨の算定を行っている.

\section{（4）降雨予測とその結果}

3. (3)と同様に，2004年に日本に上陸した台風6号を対 象として, 初期時刻を2004年6月21日午前10時とし降雨

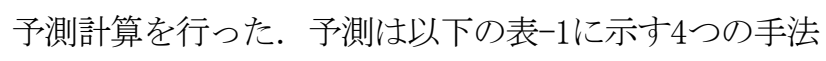
で行った. 実況降雨と 1 時間後の予測結果を図-7に示寸. 新たに提案したレーダーが高度約200mを通っていると仮 定した場合 (手法C) と, 図には示さないが高度約2000m を通っていると仮定した場合 (手法D)では，地形性降雨 が発生しうる十分な高度まで各層ごとに地形性降雨の算 定を行ったため, 100mの層厚のみを考慮した3. (3)に比べ 地形性降雨強度が大きくなった。 また, 本研究では全国 合成レーダー情報を用いているため, レーダーが通過し ている高度が正確にはわからない，そこで，手法Cと， 手法Dの 2 つ場合で地形性降雨の算定を行ったが，女 まり差異が見受けられなかった。ゆえに，観測された レーダー情報の高度についてあまり厳密に配慮する必要 はことを示している.

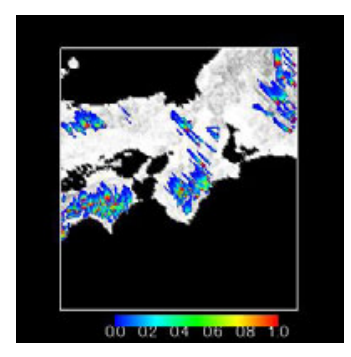

高度 $1000 \mathrm{~m}$

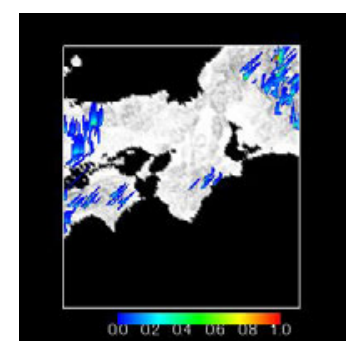

高度 $4000 \mathrm{~m}$

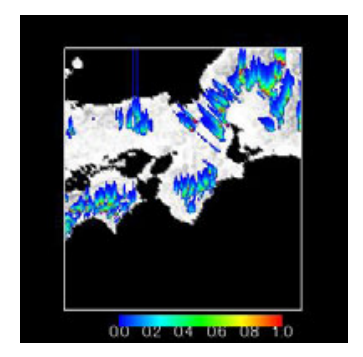

高度 $2000 \mathrm{~m}$

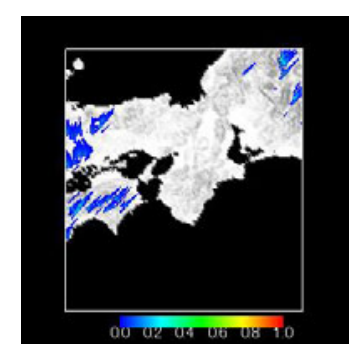

高度 $5000 \mathrm{~m}$
図-5 各々の層での雲水量 (高度は $\sigma$ 座標系)

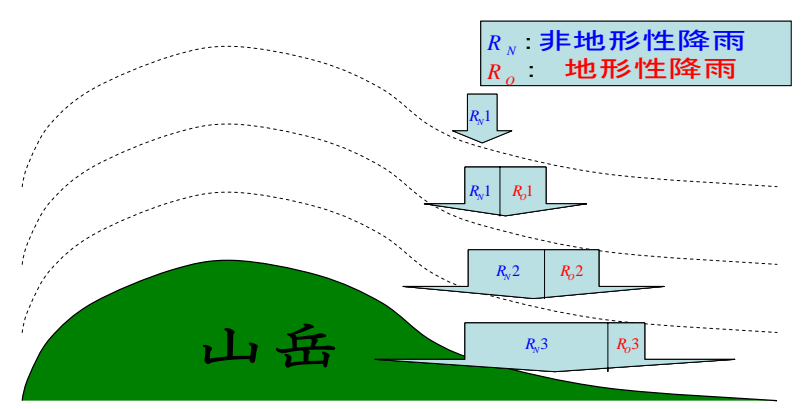

図-6 複数の層を考慮した地形性降雨の算定 


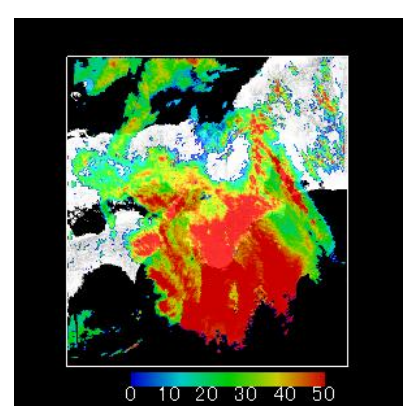

初期時刻 (午前10時) 実況降雨

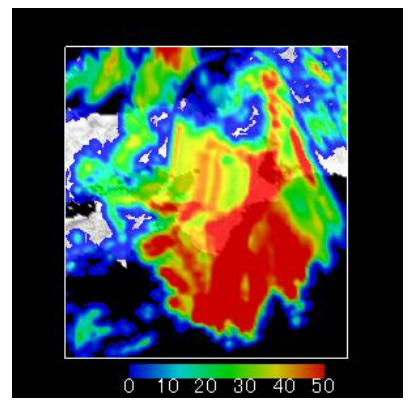

予測降雨 (手法A)

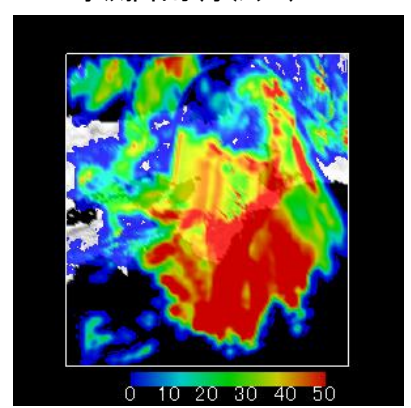

予測降雨 (手法 C)

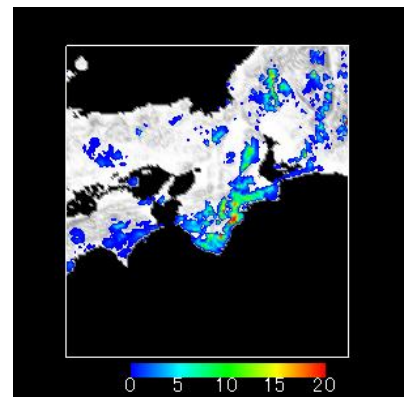

予測地形性降雨 (手法B)

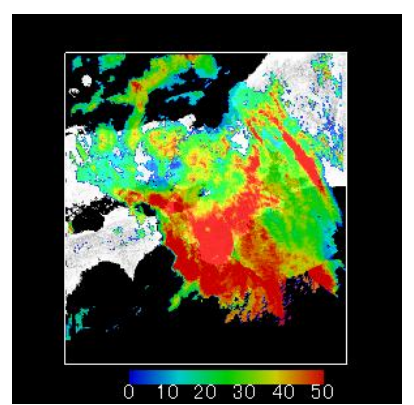

1時間後 (午前11時) 実況降雨

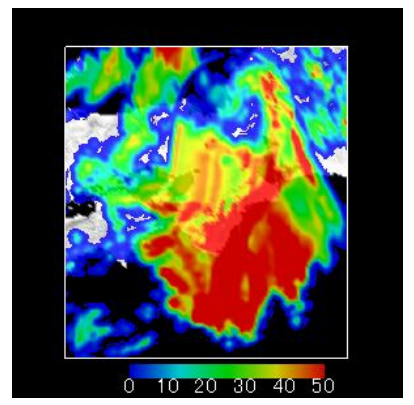

予測降雨 (手法B)

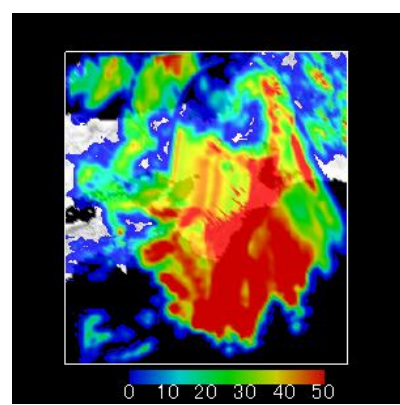

予測降雨 (手法D)

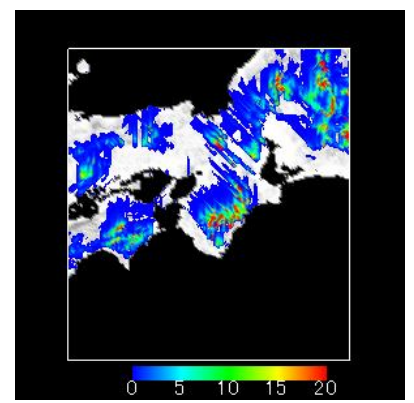

予測地形性降雨 (手法 C)

図-7 実況降雨と1時間後の予測降雨

表-1＼cjkstart各々の手法の説明

\begin{tabular}{|c|l|}
\hline 手法 $\mathrm{A}$ & 地形性降雨導入なし \\
\hline 手法 $\mathrm{B}$ & $\begin{array}{l}\text { 地形性降雨の非地形性降雨に関する線形性を仮定し } \\
\text { た従来の手法 }\left(\text { 中北ら }{ }^{2)}\right)\end{array}$ \\
\hline 手法 $\mathrm{C}$ & $\begin{array}{l}\text { 最下層における地形性降雨と非地形性降雨の合成を } \\
\text { レーダー観測降雨と仮定した手法 }\end{array}$ \\
\hline 手法D & $\begin{array}{l}\text { 地上から高度が約 } 2000 \mathrm{~m} \text { の地形性降雨と非地形性降雨 } \\
\text { の合成をレーダー観測降雨と仮定した手法 }\end{array}$ \\
\hline
\end{tabular}

\section{5. 結論}

以上，本研究により，以下の4つのことが判明した.

（i ）地形性降雨に対する非地形性降雨の非線形効果 を考慮すると，地形性降雨強度が小さくなる.

（ii）（i ）より線形性を仮定した手法(中北ら ${ }^{2)}$ )で用い られていた層厚100[m]は，大変薄いものであった。

（iii）地形性降雨が発生しうる十分な高度まで各層ご とに地形性降雨の算定を行ったところ，（i ）に比 べ地形性降雨強度が大きくなった。

（iv）本来，レーダーが通っている高度で，観測して いる降雨強度が地形性降雨強度と非地形性降雨強 度の和であると考えるべきである，本研究では全 国合成レーダー情報を用いているため，レーダー が通過している高度が正確にはわからない。そこ で，レーダーが高度約 $200 \mathrm{~m}$ 通っていると仮定し た場合 (手法C) と，高度約2000mを通っていると 仮定した場合 (手法D)の 2 つ場合で地形性降雨 の算定を行ったが，あまり差異が見受けられな かった．ゆえに，観測されたレーダー情報の高度 についてあまり厳密に配慮する必要はないことを 示している.

今後の方針としては，台風以外の降雨事例にも本研究 で示した非線形効果と複数層を導入し，様々な事例で検 証を行い，地形性降雨について検討をする予定である.

\section{参考文献}

1）椎葉充晴・高棹环馬・中北英一：移流モデルによる短時 間降雨予測手法の検討，第28 回水理講演会論文集， pp. 349-354, 1994.

2）中北英一・足立充・北井剛 : 地形性降雨を導入したレー ダーおよびGPV情報を用いた台風性降雨予測手法の開発，水工 学論文集，第51巻，2007年2月

3）立平良三:雨滴成長を考慮した地形性降雨の計算，天気， Vol23, No2, pp.95-100,1976.

4) Kataoka, K., H. Daitou, K. Kamisaka, S. Ikebuchi, E. Nakakita, S. Oishi, A. Fujita and N. Takada: Study on orographic rainfall characteristics and short-term prediction using radar data in mountainous region, Proc. of 5th Int. Symp. on Hydrological Applications of Weather Radar, Kyoto, Japan, pp.305-310, 2001. 5) Nakakita, E., S. Ikebuchi, T. Nakamura, M. Kanmuri, M. Okuda, A. Yamaji and T. Takasao : Short-term rainfall prediction method using a volume scanning radar and GPV data from numerical weather prediction, Journal of Geophysical Research, Vol. 101, No. D21, pp.26181-26197, 1996.

(2007. 9. 30受付) 